\title{
Hubungan Antara Motivasi Belajar dan Media Pembelajaran dengan Hasil Belajar Matematika
}

\author{
Ni Putu Eka Windi Putri Pertiwi ${ }^{1}$, I Made Suarjana ${ }^{2}$, Ni Wayan Arini ${ }^{3}$ \\ ${ }^{123}$ Jurusan Pendidikan Guru Sekolah Dasar \\ Universitas Pendidikan Ganesha \\ Singaraja, Indonesia \\ e-mail: putriwindi60@gmail.com, imade.suarjana@undiksha.ac.id, wayanarini@yahoo.co.id
}

\begin{abstract}
Abstrak
Penelitian ini bertujuan untuk mengetahui (1) hubungan antara motivasi belajar dengan hasil belajar matematika siswa, (2) hubungan antara media pembelajaran dengan hasil belajar matematika siswa, (3) hubungan antara motivasi belajar dan pengggunaan media pembelajaran dengan hasil belajar matematika siswa. Metode yang digunakan dalam penelitian ini yaitu deskriptif kuantitatif korelasional. Populasi penelitian adalah seluruh siswa di Gugus III kelas V, sebanyak 151 siswa. Sampel yang digunakan sebanyak 126 siswa dengan teknik Random Sampling. Teknik pengumpulan data menggunakan teknik angket dan dokumentasi. Teknik analisis data menggunakan analisis Regresi sederhana dan Regresi Ganda. Hasil analisis menunjukkan (1) Adanya hubungan positif yang signifikan antara motivasi belajar dengan hasil belajar matematika siswa. Hasil koefisien korelasi sebesar 0,733 dan koefisien determinasi sebesar $53,7 \%$ dengan rhitung $0,733>$ rtabel 0,176 maka $\mathrm{H} 0$ ditolak yang berarti signifikan dan besar koefisien determinasinya $R$ Square $=0,537$ jadi $0,537 \times 100 \%=53,7 \%$, (2) Adanya hubungan positif yang signifikan antara media pembelajaran siswa dengan hasil belajar matematika. Hasil koefisien korelasi sebesar 0,775 dan koefisien determinasi sebesar $60,1 \%$ dengan rhitung $0,775>$ rtabel 0,176 maka $\mathrm{H} 0$ ditolak yang berarti signifikan dan besar koefisien determinasinya R Square $=0,601$ jadi $0,601 \times 100 \%=60,1 \%$, (3) Adanya hubungan positif yang signifikan secara bersama antara motivasi belajar dan media pembelajaran dengan hasil belajar matematika. Hasil koefisien korelasi sebesar 0,810 dan koefisien determinasi sebesar $65,7 \%$ dengan rhitung $0,810>$ rtabel 0,176 maka $\mathrm{H} 0$ ditolak yang berarti signifikan dan besar koefisien determinasinya $\mathrm{R}$ Square $=0,657$ jadi $0,657 \times 100 \%=65,7 \%$.
\end{abstract}

Kata Kunci: Motivasi belajar, media pembelajaran, hasil belajar matematika.

\begin{abstract}
The purposes of this research are to know: (1) the relationship between learning motivation and mathematics learning outcomes of students, (2) the relationship between the used of learning media with students' mathematics learning outcomes, (3) the relationship between learning motivation and learning media utilization with student learning achievement. The method used in this research is descriptive correlation. The population of this research includes all of V grade students of Gugus III with total of 151 students. The sample that used is total of 126 students with Random Sampling technique. Data writing techniques using questionnaires and documentation techniques. The data analysis technique using Simple Regression and Double Regression analysis. The result of the analysis shows (1) There was significant positive correlation between learning motivation and student learning achievement. Result of coefficient of call equal to 0,733 and coefficient of determination equal to 53,7\% with rcount 0,733> rtable 0,176 then $\mathrm{HO}$ was rejected this means significant and big coefficient determinasi $R$ Square $=0,537$ so $0,537 \times 100 \%=53,7 \%$, (2) significant between the use of student learning media and mathematics learning outcomes. Result of coefficient of call equal to 0,775 and coefficient of determination equal to $60,1 \%$ with rcount $0,775>$ rtable 0,176 then HO was rejected this means significant and big coefficient of determination $R$ Square $=0,601$ become $0,601 \times 100 \%=60,1 \%$, (3) which is significant together between learning and use of learning media with the result of learning mathematics. The result of moving coefficient equal to 0,810 and coefficient of determination equal to $65,7 \%$ with rhitung $0,810>$ rtable 0,176 then $\mathrm{HO}$ was rejected means significant and big coefficient of determination $R$ Square $=0,657$ So, 0,657 $\times 100 \%=65,7 \%$.
\end{abstract}

Keywords: Learning motivation, learning media, learning result of mathematics 


\section{Pendahuluan}

Pasal 1 UU SISDIKNAS no. 20 tahun 2003 disebutkan bahwa Sistem Pendidikan Nasional adalah keseluruhan komponen pendidikan yang saling terkait secara terpadu untuk mencapai tujuan pendidikan nasional. Berangkat dari bunyi pasal ini dapat diketahui bahwa pendidikan adalah sistem yang merupakan suatu totalitas struktur yang terdiri dari komponen yang saling terkait dan secara bersama menuju kepada tercapainya tujuan (Soetarno, 2003: 2). Adapun komponen-komponen dalam pendidikan nasional antara lain adalah lingkungan, sarana-prasarana, sumberdaya, dan masyarakat. Komponen-komponen tersebut bekerja secara bersama-sama, saling terkait dan mendukung dalam mencapai tujuan pendidikan (Munirah, 2015).

Matematika sebagai salah satu ilmu dasar memiliki nilai esensial dalam kehidupan sehari-hari. Perlu disadari bahwa dengan dibelajarkannya matematika kepada semua peserta didik mulai dari jenjang pendidikan dasar sampai jenjang pendidikan menengah adalah untuk membekali mereka berbagai kemampuan.

Pada pembelajaran matematika perlu dirancang proses belajar mengajar yang baik agar tercipta suasana lingkungan yang memungkinkan seseorang melaksanakan kegiatan belajar. Setiap siswa mempunyai pandangan yang berbeda tentang pelajaran matematika. Ada siswa yang memandang matematika sebagai mata pelajaran yang menyenangkan dan ada juga siswa yang memandang matematika sebagai pelajaran yang sulit. Bagi siswa yang menganggap matematika menyenangkan maka akan tumbuh motivasi dalam diri siswa tersebut untuk mempelajari matematika dan optimis dalam menyelesaikan masalah-masalah yang bersifat menantang dalam pelajaran matematika. Sebaliknya, bagi siswa yang menganggap matematika sebagai pelajaran yang sulit, maka siswa tersebut akan bersikap pesimis dalam menyelesaikan masalah matematika dan kurang termotivasi untuk mempelajarinya.

Dengan adanya motivasi maka akan meningkatkan hasil belajar matematika siswa. Peningkatan hasil belajar siswa tidak terlepas dari beberapa faktor yaitu, adanya motivasi dan media pembelajaran siswa. Apabila faktor tersebut terpenuhi maka akan menghasilkan peningkatan hasil belajar siswa. Dalam sebuah sekolah pasti memerlukan media pembelajaran untuk melangsungkan proses belajar mengajar. Hal ini merupakan faktor yang harus diperhatikan karena mempengaruhi kelangsungan proses belajar mengajar di sekolah.

Hasil observasi yang dilakukan di SD pada gugus III Kecamatan Jembrana Kabupaten Jembrana khususnya pada kelas $\mathrm{V}$ ditemukan keadaan media pembelajaran sekolah masih kurang memadai. (1) Terlihat bahwa masih ditemukan siswa yang kurang memiliki sumber belajar sehingga mempersulit siswa dalam proses pembelajaran, (2) Guru kurang menggunakan media pembelajaran sebagai penunjang berhasilnya proses pembelajaran, (3) Pada saat proses pembelajaran berlangsung guru cenderung menggunakan metode ceramah tanpa memberikan suatu pemahaman yang memudahkan siswa untuk memahami pembelajaran sehingga pembelajaran masih cenderung bersifat abstrak. Hal ini akan berdampak buruk pada hasil belajar siswa. Salah satunya siswa kurang aktif dalam pembelajaran karena, kurangnya media pembelajaran yang digunakan. Sehingga siswa menjadi kurang termotivasi untuk mengetahui suatu hal atau sulit dalam memahami materi yang dipelajarinya.

Hasil wawancara pada tanggal 5 Desember 2017 bersama guru kelas V di Gugus III Kecamatan Jembrana Kabupaten Jembrana diketahui bahwa hasil belajar yang diperoleh siswa masih belum memuaskan, khusunya pada mata pelajaran Matematika. Hal ini disebabkan karena minimnya media pembelajaran yang digunakan, sehingga menyebabkan siswa menjadi kurang aktif saat proses pembelajaran. Media pembelajaran seperti media dan sumber belajar siswa yang ada disekolah kurang memadai, sedangkan untuk menumbuhkan motivasi siswa, diperlukan media dan sumber belajar yang memadai agar siswa mampu memahami materi yang diberikan oleh guru.

Pernyataan tersebut diperkuat dengan pencatatan dokumen yang diperoleh dari guru mata pelajaran Matematika. Pencatatan dokumen tersebut berupa UAS siswa kelas V Semester I. Nilai rata-rata UAS mata pelajaran Matematika siswa dapat dilihat pada tabel 1.

Tabel 1. Data UAS Mata Pelajaran Matematika Siswa Kelas V

\begin{tabular}{llllll}
\hline No. & Nama Sekolah Kelas & Jumlah Siswa & KKM & Nilai Rata-Rata \\
\hline 1 & SD Negeri 1 Dauhwaru V & 13 siswa & 63 & 62,51 \\
2 & SD Negeri 2 Dauhwaru V & 20 siswa & 70 & 67,15 \\
\hline
\end{tabular}




\begin{tabular}{lllll}
\hline 3 & SD Negeri 3 Dauhwaru V & 50 siswa & 71 & 68,80 \\
4 & SD Negeri 4 Dauhwaru V & 25 siswa & 70 & 67,15 \\
5 & SD Negeri 5 Dauhwaru V & 16 siswa & 63 & 62,51 \\
6 & SD Negeri 6 Dauhwaru V & 25 siswa & 70 & 67,15 \\
\hline
\end{tabular}

(Sumber: Dokumen Wali Kelas V di Gugus III Kecamatan Jembrana Kabupaten Jembrana

Tahun 2017)

Data nilai rata-rata hasil UAS mata pelajaran Matematika siswa kelas $V$ dapat dinyatakan bahwa nilai hasil belajar Matematika perlu ditingkatkan. Nilai rata-rata yang diperoleh siswa masih berada di bawah Kriteria Ketuntasan Minimal (KKM). Rendahnya hasil belajar dipengaruhi oleh kualitas guru dalam mengajar.

Guru adalah komponen yang sangat menentukan dalam implementasi suatu strategi pembelajaran. Keberhasilan dalam proses pembelajaran dipengaruhi oleh cara guru dalam menyampaikan materi pembelajaran.

Guru merupakan suatu pekerjaan yang mulia. Apabila, para guru melakukan tugasnya secara ikhlas dan berdasarkan suara hatinya, maka mereka sudah memiliki "tiket masuk surga". Apabila, guru dalam mendidik muridnya dilandasi dengan kasih sayang, maka mereka juga akan mendapat tambahan bonus dicintai oleh para muridnya. Dengan demikian, guru yang baik akan memperoleh tiga "gaji" sekaligus. Yaitu, "gaji" ekonomis (uang), "gaji" teologis (amal ibadah), dan "gaji" sosial (kesan dan ingatan yang baik dari para muridnya, paling tidak didoakan) (Warsono, 2017).

Guru dalam Kamus Besar Bahasa Indonesia berarti orang yang pekerjaannya (mata pencahariannya, profesinya) mengajar (Pusat Bahasa Departemen Pendidikan Nasional, 2005: 509). Pengertian ini memberi kesan bahwa guru adalah orang yang melakukan kegiatan dalam bidang mengajar. Istilah guru sinonim dengan kata pengajar dan sering dibedakan dengan istilah pendidik. Perbedaan ini dalam pandangan Muh. Said dalam Rusn (2009: 62- 63) dipengaruhi oleh kebiasaan berpikir orang Barat, khususnya orang Belanda yang membedakan kata onderwijs (pengajaran) dengan kata opveoding (pendidikan). Pandangan ini diikuti oleh tokoh-tokoh pendidikan di dunia Timur, termasuk tokoh-tokoh pendidikan di kalangan muslim (Shabir, 2015).

Belajar merupakan komponen ilmu pendidikan yang berkenaan dengan tujuan dan bahan acuan interaksi, baik yang bersifat eksplisit maupun implisit (tersembunyi). Kegiatan atau tingkah laku belajar terdiri dari kegiatan psikis dan fisis yang saling bekerjasama secara terpadu dan komprehensif integral (Sagala, 2012: 11 - 12) (Winanti, 2017).

Motivasi belajar dan media pembelajaran yang lengkap sangat mendukung proses pembelajaran. Motivasi belajar siswa antara yang satu dengan yang lainnya tidak sama. Hal ini bergantung pada keinginan atau tuntutan yang harus dipenuhi. Proses pembelajaran akan berhasil jika siswa mempunyai motivasi dalam belajar. Oleh karena itu, guru perlu menumbuhkan motivasi belajar siswa.

Motivasi akan membangkitkan semangat dalam belajar. Apabila motivasi siswa dalam belajar tinggi, maka hasil belajarnya akan optimal dan sebaliknya jika motivasi belajar siswa rendah, maka hasil belajar akan menjadi kurang maksimal. Salah satu hal yang mempengaruhi motivasi siswa dalam belajar adalah pengggunaan media pembelajaran yang digunakan dalam proses belajar mengajar.

Tanpa adanya media pembelajaran yang memadai, kegiatan belajar menagajar di sekolah akan terhambat. Dalam proses pembelajaran media pembelajaran diperlukan untuk menunjang proses belajar mengajar diantaranya yaitu buku, media maupun perlengkapan kelas yang diperlukan. Jadi, setiap mata pelajaran memerlukan media pembelajaran yang berbeda. Karena tersedianya media pembelajaran di lingkungan sekolah yang lengkap disertai pemanfaatan yang maksimal oleh siswa akan membantu mengembangkan pengetahuan dan meningkatkan hasil belajar siswa.

Jadi, keberhasilan belajar seorang siswa juga dipengaruhi oleh media pembelajaran yang ada di sekolah. Dengan adanya media pembelajaran yang memadai, siswa akan termotivasi dan lebih mudah dalam mengerjakan kegiatan-kegiatan yang berhubungan dengan mata pelajaran yang ada disekolah dan siswa akan lebih maju dalam belajar serta mencapai hasil belajar yang maksimal.

Dengan demikian kelengkapan media pembelajaran yang ada sangat mempengaruhi motivasi belajar siswa. Dengan meningkatnya motivasi belajar siswa, hasil belajar matematika akan meningkat. 
Berdasarkan latar belakang di atas, maka dilakukan penelitian dengan judul "Hubungan antara Motivasi Belajar dan Media Pembelajaran dengan Hasil Belajar Siswa Kelas V SD di Gugus III Kecamatan Jembrana Kabupaten Jembrana Tahun Pelajaran 2017/2018".

\section{Metode}

Penelitian ini dapat diklasifikasikan ke dalam penelitian ex-post facto. Dalam penelitian ini terdapat dua variabel bebas dan satu variabel terikat. Paradigma penelitian ini adalah paradigma ganda dengan variabel bebas motivasi belajar (X1) dan media pembelajaran (X2) dan variabel terikat hasil belajar $(\mathrm{Y})$. Untuk mencari hubungan $\mathrm{X} 1$ dengan $\mathrm{Y}$ dan $\mathrm{X} 2$ dengan $\mathrm{Y}$, menggunakan teknik korelasi sederhana.

Tempat penelitian ini adalah SD di Gugus III Kecamatan Jembrana Kabupaten Jembrana dan waktu pelaksanaannya pada bulan april tahun pelajaran 2017/2018. Populasi yang digunakan adalah keseluruhan siswa kelas V SD di Gugus III kecamatan Jembrana kabupaten Jembrana tahun pelajaran 2017/2018. Populasi Siswa dapat dilihat pada tabel 3.1 sebagai berikut

Tabel 2. Rincian Populasi Penelitian Siswa Kelas V SD Di Gugus III Kecamatan Jembrana Kabupaten Jembrana

\begin{tabular}{|c|c|c|}
\hline Sekolah & Kelas & Jumlah Siswa \\
\hline SD No 1 Dauhwaru & $\mathrm{V}$ & 13 siswa \\
\hline SD No 2 Dauhwaru & $\mathrm{V}$ & 20 siswa \\
\hline SD No 3 Dauhwaru & $\mathrm{V}$ & 52 siswa \\
\hline SD No 4 Dauhwaru & V & 25 siswa \\
\hline SD No 5 Dauhwaru & V & 16 siswa \\
\hline $\begin{array}{l}\text { SD No } 6 \text { Dauhwaru } \\
\text { Jumlah }\end{array}$ & V & $\begin{array}{c}25 \text { siswa } \\
151\end{array}$ \\
\hline
\end{tabular}

Pada penelitian ini sesuai dengan prosedur pengambilan sampel, (1) kerangka sampling ada pada tabel populasi), (2) penentuan jumlah sampel sesuai dengan yang tertera pada tabel Isaac dan Michael pada taraf signifikansi 5\% (dilampirkan) dengan $N=126$ yaitu 100, (3) tentukan alat pemilihan sampel yang digunakan yaitu pengundian.

Sampel yang digunakan sebanyak 126 siswa yang tersebar dalam 5 kelas yaitu SDN 1 Dauhwaru, SDN 2 Dauhwaru, SDN 3 Dauhwaru, SDN 4 Dauhwaru, SDN 5 Dauhwaru. Teknik pengumpulan data menggunakan teknik angket dan dokumentasi. Setelah diperoleh data terlebih dahulu dianalisis dengan menggunkan uji validitas tes dan reabilitas tes. Teknik analisis data dalam penelitian ini menggunakan dua jenis yaitu menggunakan analisis Untuk memenuhi Persyaratan uji statistic diatas, maka perlu dilakukan uji prasyarat analisis yang meliputi uji normalitas, uji linieritas, uji multikolinieritas dan uji hipotesis.

\section{Hasil dan Pembahasan}

Dari Hubungan antara motivasi belajar dan media pembelajaran dengan hasil belajar matematika siswa kelas V SD di gugus III Kecamatan Jembrana Kabupaten Jembrana Tahun Pelajaran 2017/2018 menggunakan non tes berjumlah 30 butir dalam bentuk kuesioner. Setiap butir pernyataan memiliki skor yang berbeda berkisar 1-5 sehingga, skor maksimal ideal tes yaitu 150 dan skor minimal idealnya yaitu 30 .

Hasil kuisioner motivasi belajar dengan kategori sangat tinggi sebanyak 0 orang dengan persentase $0,00 \%$, kategori tinggi sebanyak 32 orang dengan persentase $25,40 \%$, kategori sedang sebanyak 75 orang dengan persentase $59,52 \%$, kategori rendah sebanyak 19 orang dengan persentase $15,08 \%$, dan kategori rendah sekali 0 orang dengan persentase $0,00 \%$. Dengan total responden sebanyak 126 orang. Berikut disajikan gambar 4.1 distribusi frekuensi motivasi belajar dalam bentuk grafik histogram 


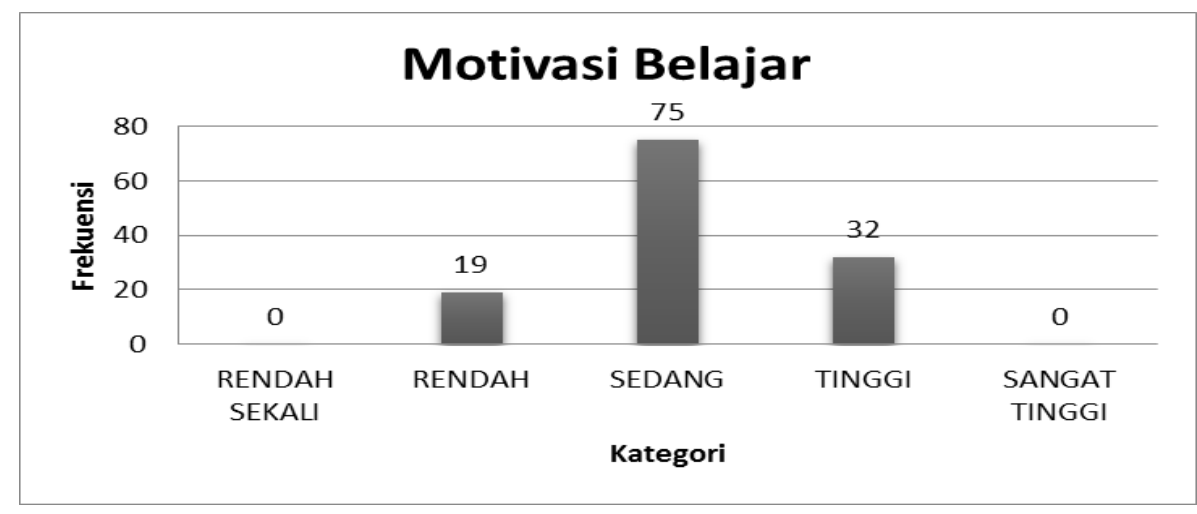

Gambar 1. Histogram Motivasi belajar

Hasil media pembelajaran dengan kategori sangat tinggi sebanyak 51 orang dengan persentase $40,48 \% \%$, kategori tinggi sebanyak 65 orang dengan persentase $51,59 \%$, kategori sedang sebanyak 10 orang dengan persentase $7,94 \%$, kategori rendah sebanyak 0 orang dengan persentase $0 \%$, dan kategori rendah sekali 0 orang dengan persentase $0 \%$. Dengan total responden sebanyak 126 orang. Berikut disajikan gambar 4.2 distribusi frekuensi media pembelajaran dalam bentuk grafik histogram.

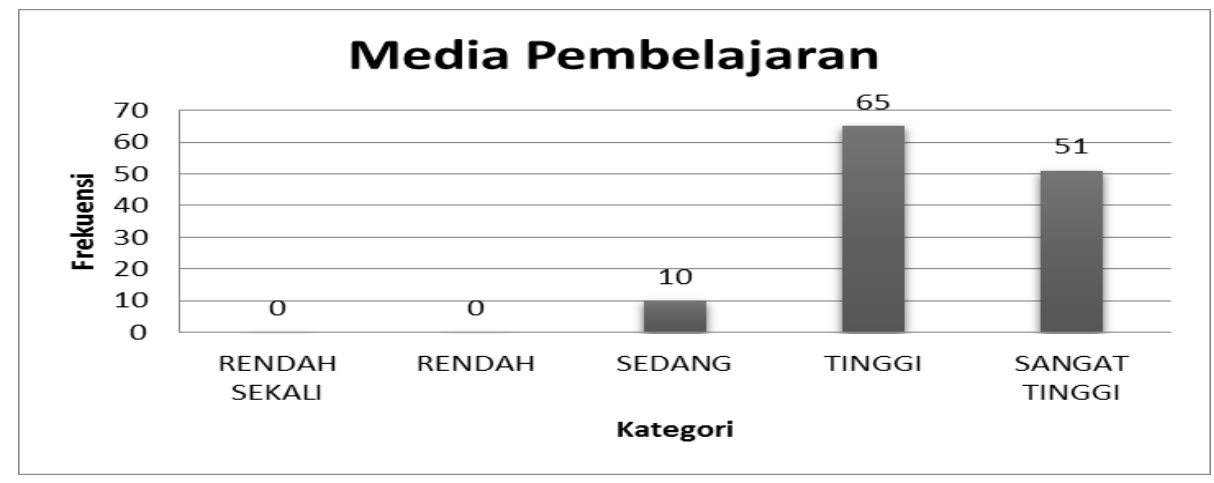

Gambar 2. Histogram Media Pembelajara

Hasil belajar siswa dengan kategori sangat tinggi sebanyak 16 orang dengan persentase $12,70 \%$, kategori tinggi sebanyak 63 orang dengan persentase $50,00 \%$, kategori sedang sebanyak 42 orang dengan persentase $33,33 \%$, kategori rendah sebanyak 0 orang dengan persentase $0,00 \%$, dan kategori rendah sekali 0 orang dengan persentase $0,00 \%$. Dengan total responden sebanyak 126 orang. Berikut disajikan gambar 4.3 distribusi frekuensi hasil belajar dalam bentuk grafik histogram.

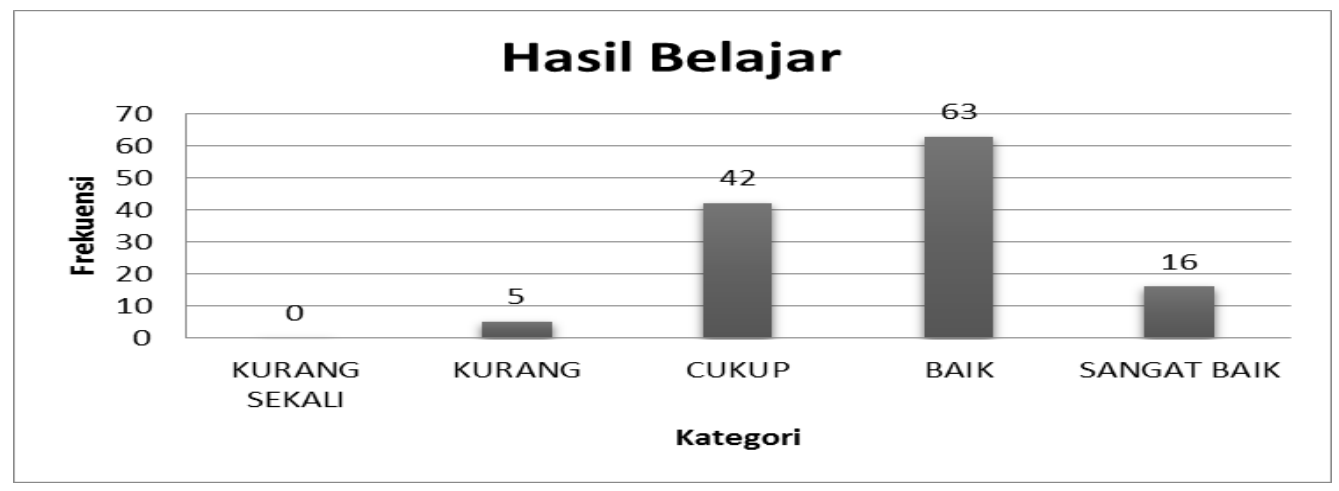

Gambar 3. Histogram Hasil Belajar 
Uji Normalitas dilakukan untuk mengetahui apakah sebaran data frekuensi skor pada setiap variabel berdistribusi normal atau tidak. Untuk uji normalitas sebaran data digunakan uji Chi-Kuadrat dengan rumus sebagai berikut dan berbantuan SPSS

Tabel 3. Hasil Uji Normalitas

\begin{tabular}{ccc}
\hline Variabel & Chi-Square & Signifikansi \\
\hline Motivasi Belajar & 44,698 & 0,180 \\
Media Pembelajaran & 55,429 & 0,116 \\
Hasil Belajar & 17,698 & 0,060 \\
\hline
\end{tabular}

Kriteria yang digunakan dengan membandingkan nilai 0,05 dengan nilai signifikan. Apabila $0,05<$ signifikansi maka dinyatakan sebaran data berdistribusi normal. Pada tabel 4.4 didapat signifikansi lebih besar dari 0,05 sehingga dapat dinyatakan sebaran data normal.

Uji multikolinieritas perlu dilakukan untuk mengetahui apakah terdapat hubungan/korelasi yang cukup tinggi antara variabel bebas. Jika terdapat hubungan yang cukup tinggi, berarti ada aspek yang sama diukur pada variabel bebas. Hal ini tidak layak digunakan untuk menentukan kontribusi secara bersama-sama variabel bebas terhadap variaber terikat. Rumus yang digunakan untuk uji multikolinieritas adalah Korelasi Product Moment Karl Person dan berbantuan SPSS. Kriteria yang digunakan yaitu Jika $<0,800$ maka dinyatakan menerima Ho sehingga antar sesama variabel bebas tidak terjadi multikolinieritas.

Tabel 4. Hasil Uji Multikolinieritas Correlations

\begin{tabular}{|c|c|c|c|c|}
\hline & & $\mathrm{X} 1$ & $\overline{x 2}$ & $\mathrm{Y}$ \\
\hline \multirow{3}{*}{$\mathrm{X} 1$} & Pearson Correlation & 1 & $.741^{\prime \prime}$ & $.733^{*}$ \\
\hline & Sig. (2-tailed) & & .000 & .000 \\
\hline & $\mathrm{N}$ & 126 & 126 & 126 \\
\hline \multirow{3}{*}{$\mathrm{X} 2$} & Pearson Correlation & $.741^{\star \pi}$ & 1 & $.775^{* *}$ \\
\hline & Sig. (2-tailed) & .000 & & .000 \\
\hline & $\mathrm{N}$ & 126 & 126 & 126 \\
\hline \multirow{3}{*}{$\mathrm{Y}$} & Pearson Correlation & $.733^{* x}$ & $.775^{*}$ & 1 \\
\hline & Sig. (2-tailed) & .000 & .000 & \\
\hline & $\mathrm{N}$ & 126 & 126 & 126 \\
\hline
\end{tabular}

Pada Tabel 4 didapat $=0,741$, sehingga $0,741<0,800$ maka dinyatakan menerima Ho sehingga antar sesama variabel bebas tidak terjadi multikolinieritas. Uji linieritas regresi ini digunakan untuk model regresi linier sehingga uji linieritas dilakukan untuk mengetahui bentuk hubungan masing-masing variabel bebas dengan variabel terikat Kriteria yang digunakan yaitu jika sgnifikan > dari 0,05, maka dinyatakan bahwa bentuk regresinya tidak linier, dan sebaliknya jika sgnifikan < dari 0,05, maka dinyatakan bentuk regresinya linier. Uji linieritas menggunakan uji F dengan rumus sebagai berikut dan berbantuan dengan SPSS.

Tabel 5. Hasil Uji Linieritas

\begin{tabular}{ccccc}
\hline \multicolumn{2}{c}{ Pasangan Variabel } & \multicolumn{2}{c}{ From Linearity } & Keterangan \\
\hline Bebas & Terikat & $\mathrm{F}$ & Sig. & \\
X1 & Y & 176,300 & 0,000 & Berarti \\
X2 & Y & 238,367 & 0,000 & Berarti \\
\hline
\end{tabular}

Pada Tabel 5 dapat dilihat bahwa signifikansi antara hubungan variabel lebih kecil dari 0,05 , sehingga dapat dinyatakan bahwa bentuk uji regresi linier

Kriteria yang digunakan dengan membandingkan nilai 0,05 dengan nilai signifikan. Apabila $0,05<$ signifikansi maka dinyatakan sebaran data berdistribusi normal. Pada tabel 4.4 didapat signifikansi lebih besar dari 0,05 sehingga dapat dinyatakan sebaran data normal.

Pengujian hipotesis yang diajukan pada penelitian ini telah menghasilkan rangkuman hasil uji hipotesis sebagai berikut: Terdapat hubungan yang signifikan antara Motivasi belajar dan Media Pembelajaran dengan Hasil Belajar Matematika siswa kelas V SD di Gugus III Kecamatan Jembrana Kabupaten Jembrana Tahun Pelajaran 2017/2018. 
Hasil analisis menunjukkan motivasi belajar dan media pembelajaran memiliki hubungan dengan hasil belajar matematika. Dalam proses belajar motivasi sangat diperlukan. Koeswara (dalam Dimyati dan Mudjiono, 2006:80) menyatakan "motivasi belajar sebagai kekuatan mental yang mendorong terjadinya belajar".

Seseorang yang tidak mempunyai motivasi dalam belajar tidak akan mungkin melakukan aktivitas belajar. "Motivasi belajar adalah keseluruhan daya penggerak dari dalam diri siswa yang menimbulkan keinginan belajar, yang menjamin kelangsungan kegiatan belajar dan memberi arah pada kegitan belajar sehingga tujuan yang dikehendaki oleh subjek belajar itu dapat tercapai" (Sardiman, 2012:86). Salah satu cara untuk menumbuhkan motivasi belajar siswa adalah dengan menggunakan media pembelajaran dalam proses belajar mengajar.

Media pembelajaran membuat siswa lebih tertarik untuk mengikuti proses pembelajaran sehingga siswa termotivasi dalam mengikuti proses pembelajaran khususnya mata pelajaran matematika. Gagne (dalam Musqfiqon, 2012:27) menyatakan bahwa "media pembelajaran adalah berbagai jenis komponen dalam lingkungan siswa yang dapat merangsang siswa untuk belajar". Salah satu media pembelajaran yang digunakan adalah media gambar.

Media yang menarik dapat menumbuhkan semangat siswa dalam belajar. "Media pembelajaran adalah alat bantu untuk memberikan perangsang bagi siswa supaya proses belajar terjadi" (Briggs dalam Musfiqon, 2012:27). Media pembelajaran yang tepat pada mata pelajaran matematika dapat menumbuhkan semangat siswa dan rasa takut terhadap mata pelajaran matematika yang sulit menjadi hilang. Padahal mata pelajaran matematika sangat penting khususnya pada jenjang SD.

Mata pelajaran matematika bukan hanya sekumpulan rumus atau kegiatan berhitung saja, melainkan meningkatkan kemampuan berpikir siswa. Kemampuan ini sangat diperlukan oleh siswa, terkait dengan kebutuhan siswa untuk memecahkan masalah yang dihadapinya dalam kehidupan sehari-hari. Susanto (2013:185) menyatakan "Matematika merupakan salah satu disiplin ilmu yang dapat meningkatkan kemampuan berpikir dan berargumentasi, memberikan kontribusi dalam penyelesaian masalah sehari-hari dan dalam dunia kerja, serta memberikan dukungan dalam pengembangan ilmu pengetahuan dan teknologi". Adanya proses pembelajaran matematika yang bisa mengembangkan proses berpikir matematis serta pembelajaran yang menyenangkan bagi siswa adalah faktor yang sangat penting dalam pembelajaran matematika di SD.

Kemampuan berpikir siswa dapat ditingkatkan melalui berbagai macam usaha yang dapat dilakukan oleh guru salah satunya dengan media pembelajaran. Melalui media pembelajaran proses pembelajaran bisa lebih menarik dan menyenangkan. Siswa yang memiliki ketertarikan terhadap warna maka dapat diberikan media dengan warna yang menarik. Begitu juga halnya dengan siswa yang senang berkreasi selalu ingin menciptakan bentuk atau objek yang diinginkannya.

Media pembelajaran membuat siswa lebih tertarik untuk mengikuti proses pembelajaran sehingga siswa termotivasi dalam mengikuti proses pembelajaran khususnya mata pelajaran matematika. Media pembelajaran yang tepat pada mata pelajaran matematika dapat menumbuhkan semangat siswa dan rasa takut terhadap mata pelajaran matematika yang sulit menjadi hilang. Sehingga hasil belajar siwa meningkat

\section{Simpulan dan Saran}

Hasil penelitian dan pembahasan dapat disimpulkan bahwa: (1) Terdapat hubungan yang signifikan antara motivasi belajar dengan hasil belajar matematika siswa kelas V SD Gugus III Kecamatan Jembrana Kabupaten Jembrana Tahun Pelajaran 2017/2018. Dilihat dari hasil analisis uji hipotesis didapatkan koefisien korelasi sebesar $=0,733$ dengan hasil analisis besar koefisien korelasi $X^{\wedge *} Y$ dengan rhitung $0,733>$ rtabel 0,176 maka $\mathrm{HO}$ ditolak yang berarti signifikan. Sedangkan besar koefisien determinasinya $\mathrm{R}$ Square $=0,537$ jadi $0,537 \times 100 \%=$ $53,7 \%$. Jadi besar koefisien determinasinya adalah 53,7\%. (2) Terdapat hubungan yang signifikan antara media pembelajaran dengan hasil belajar matematika siswa kelas V SD Gugus III Kecamatan Jembrana Kabupaten Jembrana Tahun Pelajaran 2017/2018. Dilihat dari hasil analisis uji hipotesis didapatkan koefisien korelasi sebesar $=0,775$ dengan hasil analisis besar koefisien korelasi $\mathrm{X}^{\wedge *} \mathrm{Y}$ dengan rhitung $0,775>$ rtabel 0,176 maka $\mathrm{H} 0$ ditolak yang berarti signifikan. Sedangkan besar koefisien determinasinya $R$ Square $=0,601$ jadi $0,601 \times 100 \%=$ $60,1 \%$. Dengan sumbangan pengaruh media pembelajaran terhadap hasil belajar matematika adalah $60,1 \%$. (3) Terdapat hubungan yang signifikan antara motivasi belajar dan media pembelajaran dengan hasil belajar matematika siswa kelas V SD Gugus III Kecamatan 
Jembrana Kabupaten Jembrana Tahun Pelajaran 2017/2018. Dilihat dari hasil analisis uji hipotesis didapatkan koefisien korelasi sebesar $=0,810$ dengan hasil analisis besar koefisien korelasi $X^{\wedge *} Y$ dengan rhitung $0,810>$ rtabel 0,176 maka $\mathrm{HO}$ ditolak yang berarti signifikan. Sedangkan besar koefisien determinasinya $R$ Square $=0,657$ jadi $0,657 \times 100 \%=65,7 \%$. Dengan sumbangan pengaruh motivasi belajar dan media pembelajaran terhadap hasil belajar matematika adalah $65,7 \%$.

Adapun saran yang dapat disampaikan dalam hasil penelitian ini adalah sebagai berikut: (1) Disarankan kepada Kepala Sekolah hasil penelitian ini diharapkan dapat menjadi masukan yang berharga bagi kepala sekolah selaku pengambil kebijakan yang nantinya kebijakan tersebut dapat memperlancar kegiatan pembelajaran. (2) Disarankan kepada guru hasil penelitian ini diharapkan dapat menjadi masukan yang berharga sebagai upaya untuk meningkatkan hasil belajar siswa dengan memanfaatkan media pembelajaran dalam proses pembelajaran. (3) Disarankan kepada siswa hasil penelitian ini dapat bermanfaat bagi siswa dalam memupuk motivasi belajar yang ideal supaya tidak kesulitan dalam menghadapi masalah hasil belajar di sekolah. (4) disaranakan kepada eneliti lain diharapkan dapat menjadi masukan untuk melakukan penelitian yang sejenis dalam lingkup yang lebih luas. semoga penelitian ini bermanfaat bagi pihak-pihak yang melakukan penelitian ini.

\section{Daftar Pustaka}

Mudjiono dan Dimyati. 2006. Belajar dan Pembelajaran. Jakarta: PT Rineka Cipta

Mudjiono dan Dimyati. 2015. Belajar dan Pembelajaran. Jakarta: Rineka Cipta.

Musfiqon. 2012. Pengembangan Media 7 sumber Pembelajaran. Jakarta: Pt. Prestasi Pustakarya.

Munirah. 2015. Sistem Pendidikan Di Indonesia: Antara Keinginan Dan Realita . Jurnal Auladuna, Vol. 2 No. 2 Desember 2015: 233-245

Slameto. 2010. Belajar dan faktor-faktor yang Mempengaruhinya. Jakarta: Rineka Cipta.

Shabir, M. 2015. Kedudukan Guru Sebagai Pendidik . Jurnal AULADUNA, VOL. 2 NO. 2 DESEMBER 2015: 221-232

Susanto, Ahmad. 2013. Teori Belajar \& Pembelajaran di Sekolah Dasar. Jakarta: Pt Fajar Interpratama

Sardiman. A. M. 2012. Interaksi dan Motivasi Belajar Mengajar. Jakarta: PT Raja Grafindo Persada.

Subianto, Imam, dkk. 2015. Hubungan Antara Penggunaan Media Pembelajaran Dengan Hasil Belajar IPS Siswa Kelas IV SD Negeri 7 Bagelen Kabupaten Pesawaran Tahun Pelajaran 2015/2016. Jurnal fkip unila, Vol: 4 No: 7 Tahun 2016.

Trinora, Remilda, dkk. 2015. Hubungan Motivasi Belajar Dengan Hasil Belajar Siswa Kelas IV SD Negeri 2 Labuhan Ratu Kota Bandar Lampung Tahun Ajaran 2014/2015. Jurnal fkip unila, Vol: 3 No: 1 Tahun 2015.

Uno, B. Hamzah. 2008. Teori Motivasi dan Pengukurannya, Jakarta : Bumi Aksara.

Warsono. 2017. Guru: Antara Pendidik, Profesi, Dan Aktor Sosial . Journal of Society \& Media 2017, Vol. 1(1) 1-10

Winanti, Kresni. 2017. Meningkatkan Kemampuan Komunikasi Matematis dan Kedisiplinan Siswa Kelas XI SMA N 5 Semarang Melalui Model PBL Materi Transformasi Geometri. Jurnal Profesi Keguruan JPK 3 (2) (2017): 197-204 . 